\title{
Mechanism Involved in Initiation and Propagation of Receptor- Induced Intercellular Calcium Signaling in Cultured Rat Astrocytes
}

\author{
Laurent Venance, Nephi Stella, Jacques Glowinski, and Christian Giaume \\ Institut National de la Santé et de la Recherche Médicale, U114, Collège de France, 75231 Paris, Cedex 05, France
}

The mechanisms involved in the initiation and the propagation of intercellular calcium signaling (calcium waves) were studied in cultured rat astrocytes. The analysis of calcium waves, induced either by mechanical stimulation or by focal application of ionomycin, indicated that initiation was dependent on the presence of external calcium. In addition, pharmacological experiments indicate that intercellular propagation required PLC activation, integrity of $\mathrm{IP}_{3}$-sensitive internal calcium stores, and functional gap junctions. An extracellular action of ATP or glutamate and participation of voltage-dependent $\mathrm{Ca}^{2+}$ channels were tested by using enzymatic degradation, receptor antagonists, and channel blockers, respectively. Because neither the speed of propagation nor the extent of the calcium waves was affected by these treatments, these alternate mechanisms were excluded from playing a role in intercellular cal- cium signaling. Biochemical assays and focal applications of several agonists (methoxamine, carbachol, glutamate) of membrane receptors to neurotransmitters and peptides (endothelin 1) demonstrated that their ability to trigger regenerative calcium waves depended on phospholipase $C$ activity and inositol phosphate production. Thus, in rat astrocytes, initiation and propagation of calcium waves involve a sequence of intra- and intercellular steps in which phospholipase C, inositol trisphosphate, internal calcium stores, and gap junction channels play a critical role. The identification of these different events allows us to determine several targets at which the level of long-range signaling in astrocytes may be controlled.

Key words: intercellular calcium waves; glial cells; gap junctions; phospholipase $C$; $I P_{3}$ receptors; internal calcium stores; $U-73122$
Intercellular calcium signaling has been observed in a variety of cells in culture, and it may represent a general feature for cell-tocell communication (see Sanderson et al., 1994). Recently, these observations, which initially were obtained with primary cultures, have been extended to more integrated systems, because the occurrence of intercellular calcium waves has been described in hepatocytes from the intact liver (Nathanson et al., 1995; RobbGaspers and Thomas, 1995), in astrocytes from brain slice cultures (Dani et al., 1992), and in neurons from cerebral cortical slices (Yuste et al., 1995). Several cellular events involved in intercellular calcium signaling already have been identified in various preparations, indicating a rather large diversity in the mechanisms. Gap junction channels are an obvious candidate for mediating intercellular calcium signals, because they provide a direct intercellular route in most of the tissues (Bennett et al., 1991) and are permeable to calcium ions $\left(\mathrm{Ca}^{2+}\right)$ and inositol trisphosphate $\left(\mathrm{IP}_{3}\right)$ (Saez et al., 1989). Their involvement in intercellular calcium signaling has been demonstrated in several systems either by using pharmacological agents (Christ et al., 1992; Enkvist and McCarthy, 1992; Finkbeiner, 1992; Venance et al., 1995; Yuste et al., 1995) or by comparing $\mathrm{Ca}^{2+}$ responses in normal cell lines or those transfected with gap junction protein cDNA (Charles et al., 1992). Nevertheless, occasionally this intercellular pathway can be shunted by or associated with the release of a factor in the

Received Sept. 5, 1996; revised Nov. 21, 1996; accepted Dec. 23, 1996.

We thank Drs. R. Bruzzone, B. Hamon, and J. Prémont and Professor K. D. Peusner for constructive and helpful comments on this manuscript.

Correspondence should be addressed to Dr. Laurent Venance, Institut National de la Santé et de la Recherche Médicale, U114, Collège de France, 11 Place Marcelin Berthelot, 75231 Paris, Cedex 05, France.

Dr. Stella's present address: The Neurosciences Institute, 10640 John J. Hopkins Drive, La Jolla, CA 92121.

Copyright (C) 1997 Society for Neuroscience $\quad 0270-6474 / 97 / 171981-12 \$ 05.00 / 0$ extracellular space responsible for the activation of adjacent cells (Enomoto et al., 1992; Osipchuk and Cahalan, 1992). A key question concerning the mechanism of intracellular calcium signaling is the participation of intercellular $\mathrm{Ca}^{2+}$ stores, which allow an increase in intracellular $\mathrm{Ca}^{2+}$ concentration $\left(\left[\mathrm{Ca}^{2+}\right]\right)_{\mathrm{i}}$ to be transmitted from a single cell to a number of its neighbors. Depending on the cell type and the stimulus, increases in $\left[\mathrm{Ca}^{2+}\right]_{i}$ originate from two main sources, either the extracellular space or intracellular stores, which can be mobilized collectively or independently (Clapham, 1995). Thus, a release from $\mathrm{Ca}^{2+}$-sensitive internal calcium pools has been reported to play a critical role in intercellular calcium signaling between osteoblasts (Xia and Ferrier, 1992), whereas $\mathrm{IP}_{3}$-sensitive calcium stores and voltagedependent $\mathrm{Ca}^{2+}$ channels participate in this process in airway epithelial cells (Boitano et al., 1992, 1995).

In the CNS, intercellular calcium waves have been observed mainly among neurons (Yuste et al., 1995) and among glial cells, including astrocytes (Cornell-Bell et al., 1990; Charles et al., 1991) and oligodendrocytes (Takeda et al., 1995). Intercellular signaling is believed to contribute to neuronal and neuro-glial interactions (Attwell, 1994; Kandler and Katz, 1995) in addition to pathological processes such as spreading depression (Nedergaard et al., 1995) and epilepsy (Cornell-Bell and Williamson, 1993). In astrocytes, intercellular calcium signaling is of special interest because it could represent a glial form of cell excitability and a long-range signaling system that may participate actively in neuronal information processing (Cornell-Bell et al., 1990; Smith, 1994). Indeed, astrocytes are anatomically in close relation with synaptic contacts and express a variety of membrane receptors to neurotransmitters that mediate increases in $\left[\mathrm{Ca}^{2+}\right]_{\mathrm{i}}$ (Finkbeiner, 1995). Accordingly, it has been reported that the stimulation of glutamatergic neurons generates intercellular calcium waves in astrocytes from brain 
slices in culture (Dani et al., 1992). In cocultures, intercellular calcium waves induced in astrocytes can trigger $\mathrm{Ca}^{2+}$ responses in neurons (Charles, 1994; Nedergaard, 1994; Parpura et al., 1994). Altogether, these observations suggest that intercellular calcium signaling in astrocytic networks plays a critical role in information processing by contributing to a loop of reciprocal interactions with neurons (Attwell, 1994; Smith, 1994).

The present study was undertaken to detail the mechanisms underlying the initiation and propagation of intercellular calcium signaling in cultured astrocytes. The sequence of events responsible for intercellular calcium wave propagation was analyzed first with mechanical stimulation and focal application of a calcium ionophore to induce $\left[\mathrm{Ca}^{2+}\right]_{\mathrm{i}}$ increases from a single cell. Then these results were used to determine the critical steps necessary for regenerative intercellular calcium waves when triggered by the stimulation of astrocytic membrane receptors by neurotransmitters.

\section{MATERIALS AND METHODS}

Cell cultures. Pregnant Swiss mice and OFA rats (IFFA Credo, Lyon, France) were killed by prolonged exposure to a high concentration of carbon dioxide. Embryos were removed rapidly from the uteri and placed in PBS supplemented with glucose $(33 \mathrm{~mm})$. Primary cultures were prepared as previously described (El Etr et al., 1989). Striata were dissected from 16- and 18-d-old mice and rat embryos, respectively, and then mechanically dissociated in a PBS-glucose solution with a flamenarrowed Pasteur pipette. Cells were plated into (1) poly-L-ornithinecoated $(6 \mu \mathrm{g} / \mathrm{ml}) 35 \mathrm{~mm}$ diameter culture dishes $\left(2.10^{6}\right.$ cells/dish $)$ (NUNC, Roskilde, Denmark) for the scrape-loading experiments, (2) 12 $\mathrm{mm}$ diameter dishes with 24 wells $\left(3.10^{5}\right.$ cells/well) (NUNC) for the measurement of $\left[{ }^{3} \mathrm{H}\right]$ inositol phosphate formation, or (3) onto glass slides $\left(3.10^{6}\right.$ cells/slide) (Rouvier-Gassalem, Paris, France) previously coated with poly-L-ornithine $(15 \mu \mathrm{g} / \mathrm{ml})$ and natural mouse laminin $(2 \mu \mathrm{g} / \mathrm{ml})$ for the intracellular calcium-imaging experiments. Culture medium consisted of a 1:1 mixture of MEM and F-12 nutrient (Life Technologies, Gaithersburg, MD) supplemented with (in mM): glutamine 2, $\mathrm{NaHCO}_{3} 13$, HEPES 20, glucose 33, penicillin-streptomycin $(5 \mathrm{U} / \mathrm{ml}$ and $5 \mu \mathrm{g} / \mathrm{ml}$, respectively), and 5\% Nu-serum (Collaborative Research, Bedford, MA). Cells were incubated at $37^{\circ} \mathrm{C}$ for $21-25 \mathrm{~d}$ in a humidified atmosphere of $95 \%$ air $/ 5 \% \mathrm{CO}_{2}$. The culture medium was changed once per week. On day 8 , cytosine arabinoside $(2 \mu \mathrm{M})$ was added for $60 \mathrm{hr}$ to prevent fibroblast and microglia proliferation. Under these conditions, after $21 \mathrm{~d}$ in culture, $>95 \%$ of the cells stained positive for glial fibrillary acid protein (GFAP; ICN Biochemicals, Costa Mesa, CA) by the indirect immunofluorescence staining of antibodies.

Measurement of intracellular calcium. Measurements of $\left[\mathrm{Ca}^{2+}\right]_{\mathrm{i}}$ in rat cultured striatal astrocytes were achieved, as previously described (Murphy et al., 1994), under dual-emission microfluorimetry with the cellpermeant fluorescent calcium probe Indo1-AM (Sigma, St. Louis, MO). Cells were loaded for $1 \mathrm{hr}$ in the presence of Indo1-AM $(12 \mu \mathrm{M})$ in a cell incubator. After loading, the glass slide was placed in a perfusion chamber. The cells were excited by a $75 \mathrm{~W}$ xenon light filtered at $340 \mathrm{~nm}$ with a 10-nm-wide interference filter. Excitation and emission spectra were separated by a $380 \mathrm{~nm}$ dichroic long-pass filter, and then the emission spectra were divided into two halves by a dichroic long-pass filter mounted on an inverted microscope (Nikon, Tokyo, Japan). Two discriminant bands were selected from the two halves at 400-410 and $470-480 \mathrm{~nm}$, and both fluorescent images were digitized ( 8 video frames/ image). The camera dark noise was subtracted from the recorded crude image with an image processing system (Hamamatsu, Hamamatsu City, Japan).

$\left[\mathrm{Ca}^{2+}\right]_{\mathrm{i}}$ was calculated from the fluorescence ratio $(R)$ measured at $400-410$ and $470-480 \mathrm{~nm}$, according to the equation described by Grynkiewicz et al. (1985):

$$
\left[\mathrm{Ca}^{2+}\right]_{\mathrm{i}}=K_{\mathrm{D}} \cdot\left(F_{480 \mathrm{f}} / F_{480 \mathrm{~b}}\right) \cdot\left[\left(R-R_{\min }\right) /\left(R_{\max }-R\right)\right],
$$

in which the $K_{\mathrm{D}}$ of Indo1-AM for ionized calcium is $250 \mathrm{nM}, F_{480 \mathrm{f}}$ is the fluorescence of free Indo1-AM, $F_{480 \mathrm{~b}}$ is the fluorescence of probe bound to calcium, and $R$ is the ratio between fluorescences measured at 405 and $480 \mathrm{~nm} . R_{\min }$ and $R_{\max }$ were determined in the presence of ionomycin (5 $\mu \mathrm{M})$, with $1.1 \mathrm{~mm} \mathrm{CaCl}_{2}$ or $2 \mathrm{~mm}$ EGTA, respectively. The ratios were measured at 1 or $3 \mathrm{sec}$ intervals in the cell bodies of individual astrocytes. All measurements were given as ratios that ranged from 0.01 to 1.50 and corresponded to estimated $\left[\mathrm{Ca}^{2+}\right]_{\mathrm{i}}$ values of $10-2000 \mathrm{nM}$, respectively.

Measurement of $\left[{ }^{3} H\right]$ inositol phosphate formation. Striatal rat astrocytes, grown in 24-well dishes, were incubated for $24 \mathrm{hr}$ in the presence of myo- $\left[2-{ }^{3} \mathrm{H}\right]$ inositol $(4 \mu \mathrm{Ci} / \mathrm{ml})$. Cultures were washed three times with the solution used for calcium experiments $(1 \mathrm{ml} /$ well $)$ and then preincubated for $15 \mathrm{~min}$ in the same solution supplemented with lithium $(10 \mathrm{mM})$ and adenosine deaminase $(1 \mathrm{U} / \mathrm{ml})$. After treatment, the incubation was terminated by lysing the cells with successive additions of $0.1 \%$ Triton $\mathrm{X}-100$ in $0.1 \mathrm{M} \mathrm{NaOH}(400 \mu \mathrm{l})$ and then $0.1 \%$ Triton X-100 in $0.1 \mathrm{M} \mathrm{HCl}$ $(400 \mu \mathrm{l}) .\left[{ }^{3} \mathrm{H}\right] \mathrm{IP}$ was isolated in the lysate by adding $1.5 \mathrm{ml} \mathrm{CHCl} \mathrm{CH}_{3} /$ $\mathrm{CH}_{3} \mathrm{OH}(1: 2 \mathrm{v} / \mathrm{v})$, followed by $0.5 \mathrm{ml} \mathrm{CHCl}_{3}$ and centrifugation at $1000 \times$ $g$ for $5 \mathrm{~min}$. All steps were performed at $37^{\circ} \mathrm{C}$. An aliquot $(1 \mathrm{ml})$ of the upper aqueous phase was loaded onto Dowex AG $1 \times 8$ columns (formate form, 200-400 mesh, Bio-Rad, Richmond, CA), and myo-[2${ }^{3} \mathrm{H}$ ]inositol was eluted with myo-inositol $(5 \mathrm{~mm}, 4 \mathrm{ml})$. Then columns were washed with formic acid $(0.1 \mathrm{M}, 10 \mathrm{ml})$, and total $\left[{ }^{3} \mathrm{H}\right]$ inositol phosphates containing mainly $\left[{ }^{3} \mathrm{H}\right]$ monophosphate $(>90 \%$ of the total inositol phosphates) were eluted with $5 \mathrm{ml}$ of ammonium formate (1 M)/formic acid $(0.1 \mathrm{M})$. Radioactivity was measured by adding $\mathrm{H}_{2} \mathrm{O}(3 \mathrm{ml})$ and Aquasol $2(8 \mathrm{ml})$.

Determination of junctional permeability. Permeability of astrocyte gap junctions was determined by the scrape-loading/dye transfer technique, as previously described (El Fouly et al., 1987; Giaume et al., 1991b). Control experiments were performed by incubating striatal mouse astrocytes for 9 min in a standard solution containing (in $\mathrm{mM}$ ): $\mathrm{NaCl} 140, \mathrm{KCl} 5.5, \mathrm{CaCl}_{2}$ $1.8, \mathrm{MgCl}_{2} 1$, glucose 25, and HEPES 10 , with the $\mathrm{pH}$ fixed at 7.35 , and then washed for $1 \mathrm{~min}$ with the same solution in which $\mathrm{Ca}^{2+}$ was omitted to prevent uncoupling of the cells during the scrape procedure. Scrapeloading was performed with a razor blade in the calcium-free solution containing $0.1 \%$ Lucifer yellow during $1 \mathrm{~min}$ (dilithium salt, Sigma). Junctional permeability was measured 8 min after scraping by taking five successive photomicrographs per trial (Kodak TMAX, 400 ASA) with an inverted microscope (Diaphot, Nikon, Tokyo, Japan) equipped with appropriate filters. When a drug was tested, it was present in the preincubation solution and all other solutions until the photomicrograph was taken. Negatives were digitized with an image analyzer system (Imstar Software, Paris, France), and data were quantified by measuring diffusion of the dye through the astrocytes by computation of the fluorescence areas. Quantification of the effects induced by different treatments on gap junction permeability was performed by expressing the computed fluorescence area as a percentage of the internal control measured the same day on the same culture (Giaume et al., 1991b).

Cell stimulation. Mechanical stimulation was performed with a patchclamp pipette driven by a hydraulic micromanipulator to touch the top of an astrocyte gently. Experiments were rejected when the cell membrane was damaged, as revealed by a leak of the fluorescent probe from the cell. Drugs were superfused with a multichannel perfusion device, which allowed the complete change of the medium in $<400 \mathrm{msec}$. Focal application of drugs was performed by applying a pressure pulse $(276 \mathrm{kPa}, 20$ $\mathrm{msec}$ ) with a pneumatic Pico pump (PV800, World Precision Instruments, New Haven, CT) connected to a patch-clamp pipette filled with the external solution containing the tested compound. The control for the focal application of drugs was achieved by using the external standard solution alone. This resulted in no significant change in $\left[\mathrm{Ca}^{2+}\right]_{\mathrm{i}}$ recorded from the target cells $(n=6)$.

Solutions and chemicals. All experiments were performed at room temperature $\left(20-22^{\circ} \mathrm{C}\right)$ in a standard solution containing (in $\mathrm{mM}$ ): $\mathrm{NaCl}$ 145, $\mathrm{KCl} 5.5, \mathrm{CaCl}_{2}$ 1.1, $\mathrm{MgCl}_{2}$ 0.9, glucose 20, and HEPES 20 (Calbiochem, San Diego, CA), with a $\mathrm{pH}$ of 7.35 . The calcium-free solution contained (in mM): $\mathrm{NaCl} 145, \mathrm{KCl} 5.5, \mathrm{MgCl}_{2} 1.5$, HEPES 20, glucose 20, and EGTA 2, with a $\mathrm{pH}$ of 7.35.

All drugs used were purchased from Sigma, except for U-73122 and U-73343 (Biomol, Plymouth, PA), ionomycin (Boehringer Mannheim, Mannheim, Germany), myo- $\left[2-{ }^{3} \mathrm{H}\right]$ inositol (Amersham, Les Ulis, France), L(+)-2-amino-3-phosphonopropionic acid $\left(\mathrm{L}-\mathrm{AP}_{3}\right)$ and 6,7dinitroquinoxaline-2,3-dione (DNQX) (Tocris Cookson, Bristol, UK), and endothelin-1 (Neosystem, Strasbourg, France).

Statistical analysis of the data are provided as mean \pm SEM, and statistical significance was established by a one-way ANOVA, followed by post-tests. 
Table 1. Effect of agents affecting gap junctions permeability, PLC activation, or $\mathrm{Ca}^{2+}$ mobilization from internal stores on the properties of intercellular calcium signaling and junctional communication in cultured astrocytes

\begin{tabular}{|c|c|c|c|c|c|c|c|}
\hline \multicolumn{2}{|c|}{ Experimental conditions } & \multirow{2}{*}{$\begin{array}{l}\text { Number of } \\
\text { cells in the } \\
\text { field (no. of } \\
\text { experiments) } \\
34 \pm 1(54)\end{array}$} & \multirow{2}{*}{$\begin{array}{l}\text { Number of } \\
\text { responding } \\
\text { cells }(\%)\end{array}$} & \multirow{2}{*}{$\begin{array}{l}\begin{array}{l}\text { Ratio }(F 405 / F 480) \\
\text { of stimulated cell } \\
\text { (no. of cells) }\end{array} \\
1.17 \pm 0.02(55)\end{array}$} & \multirow{2}{*}{$\begin{array}{l}\text { Ratio }(F 405 / F 480) \\
\text { of the cells of the } \\
\text { first row } \\
\text { (no. of cells) } \\
0.81 \pm 0.02(336)\end{array}$} & \multirow{2}{*}{$\begin{array}{l}\begin{array}{l}\text { Velocity of } \\
\text { ICW }(\mu \mathrm{m} / \mathrm{sec}) \\
\text { (no. of cells) }\end{array} \\
16 \pm 0.7(62)\end{array}$} & \multirow{2}{*}{$\begin{array}{l}\begin{array}{l}\text { Scrape- } \\
\text { loading }(\%)\end{array} \\
100^{\mathrm{A}}\end{array}$} \\
\hline Control & Mech. stim. & & & & & & \\
\hline & Focal iono. & $32 \pm 1(33)$ & $22 \pm 1(68)$ & $0.77 \pm 0.04(33)$ & $0.53 \pm 0.02(184)$ & $16 \pm 0.9(46)$ & $100^{\mathrm{B}}$ \\
\hline \multirow{2}{*}{$\begin{array}{l}18 \alpha \text {-glycyrrhetinic } \\
\text { acid } 10 \mu \mathrm{M}\end{array}$} & Mech. stim. & $30 \pm 3(4)$ & $2 \pm 1(7)$ & $1.06 \pm 0.12(4)$ & $0.16 \pm 0.08(4)$ & - & $20 \pm 6^{\mathrm{A}}(5)$ \\
\hline & Focal iono. & $31 \pm 2(14)$ & $4 \pm 2(13)$ & $0.80 \pm 0.05(15)$ & $0.24 \pm 0.02(36)$ & - & \\
\hline \multirow[t]{2}{*}{$\mathrm{U}-731225 \mu \mathrm{M}$} & Mech. stim. & $31 \pm 1(26)$ & $5 \pm 1(15)$ & $1.03 \pm 0.03(33)$ & $0.48 \pm 0.04(62)$ & - & $100 \pm 5^{\mathrm{A}}(3)$ \\
\hline & Focal iono. & $32 \pm 1(6)$ & $4 \pm 1(14)$ & $0.54 \pm 0.07(10)$ & $0.27 \pm 0.05(15)$ & - & $102 \pm 3^{\mathrm{B}}(3)$ \\
\hline \multirow[t]{2}{*}{$\mathrm{U}-733435 \mu \mathrm{M}$} & Mech. stim. & $33 \pm 1(10)$ & $29 \pm 1(88)$ & $1.18 \pm 0.03(11)$ & $0.88 \pm 0.04(56)$ & $16 \pm 0.5(99)$ & $100 \pm 8^{\mathrm{A}}(3)$ \\
\hline & Focal iono. & $31 \pm 1(5)$ & $21 \pm 2(67)$ & $0.85 \pm 0.09(5)$ & $0.55 \pm 0.05(29)$ & $18 \pm 1.5(24)$ & $100 \pm 3^{\mathrm{B}}(3)$ \\
\hline \multirow[t]{2}{*}{ Dantrolene $10 \mu \mathrm{M}$} & Mech. stim. & $32 \pm 1(12)$ & $29 \pm 2(90)$ & $1.02 \pm 0.05(15)$ & $0.67 \pm 0.03(67)$ & $16 \pm 1(72)$ & $106 \pm 3^{\mathrm{A}}(3)$ \\
\hline & Focal iono. & $28 \pm 1(11)$ & $16 \pm 1(57)$ & $0.56 \pm 0.06(12)$ & $0.41 \pm 0.03(56)$ & $17 \pm 1(26)$ & $110 \pm 8^{\mathrm{B}}(3)$ \\
\hline \multirow[t]{2}{*}{ Thapsigargin $2 \mu \mathrm{M}$} & Mech. stim. & $31 \pm 1(11)$ & $2 \pm 0.3(5)$ & $0.86 \pm 0.08(14)$ & $0.34 \pm 0.03(17)$ & - & $91 \pm 12^{\mathrm{A}}(3)$ \\
\hline & Focal iono. & $27 \pm 2(12)$ & $1 \pm 0.3(3)$ & $0.41 \pm 0.02(12)$ & $0.26 \pm 0.04(9)$ & - & \\
\hline
\end{tabular}

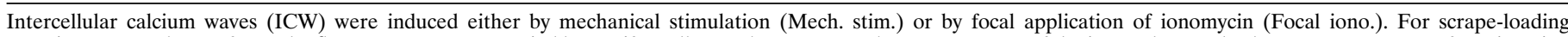

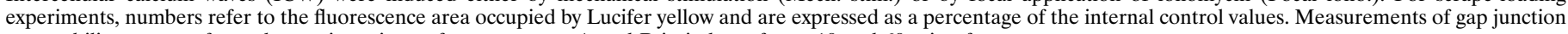
permeability were performed at various times after treatment. A and B in index refer to 10 and 60 min of exposure.

\section{RESULTS}

\section{Characteristics of intercellular calcium signaling induced by mechanical stimulation and focal application of ionomycin}

The fluorescence ratio of Indo1 emissions $\left(F_{405} / F_{480}\right)$ monitored in resting confluent cultured rat astrocytes was $0.11 \pm 0.02(n=$ $2487)$, which corresponds to a basal $\left[\mathrm{Ca}^{2+}\right]_{\mathrm{i}}$ of $89 \pm 9 \mathrm{~nm}$. The average number of cells present in the microscopic field was $31 \pm$ $1(n=313$ fields). Thus, the cellular network observed around an astrocyte selected in the center of this field was composed of approximately six to seven cellular rows defined by concentric rings around the stimulated cell (Fig. 1E, left).

Single-cell stimulation was performed either by mechanical stimulation with a micromanipulator-driven glass pipette or by a pressure application from a micropipette filled with ionomycin (50 $\mu \mathrm{M})$. As indicated by the change in the ratio of Indo1 emissions, both types of stimulation induced large increases in $\left[\mathrm{Ca}^{2+}\right]_{\mathrm{i}}$ in the stimulated cells (7- to 10 -fold times the basal level). These responses were rapidly reversed because, after $3 \mathrm{~min},\left[\mathrm{Ca}^{2+}\right]_{\mathrm{i}}$ returned to its initial value in 71 and $92 \%$ of the trials performed with mechanical stimulation and ionomycin focal application, respectively. These single-cell stimulations always were followed by delayed $\mathrm{Ca}^{2+}$ responses in surrounding astrocytes (Fig. $1 A$ ). Under control conditions, after mechanical stimulation and ionomycin focal application, intercellular calcium signaling affected 84 and $68 \%$, respectively, of the cells present in the microscopic field and had similar speeds of propagation $(\sim 15-20 \mu \mathrm{m} / \mathrm{sec})$ at room temperature (Table 1).

As illustrated in Figure 2, quantitative analysis indicated that the amplitude of $\mathrm{Ca}^{2+}$ responses decreased with distance from the stimulated cell and reached a stable value in distal cellular rows. This feature was observed particularly for ionomycin application, because the extension of intercellular calcium signaling was limited to the size of the microscopic field (Fig. 1A). When mechanical stimulations were performed, more cells responded, and in most cases propagation went farther than the microscopic field usually investigated, as indicated when an objective of lower power magnification $(20 \times$ instead of $40 \times)$ was used. Although the amplitude of the $\mathrm{Ca}^{2+}$ response in the stimulated cells was sig- nificantly different according to the mode of stimulation, the amplitude of $\left[\mathrm{Ca}^{2+}\right]_{\mathrm{i}}$ changes in astrocytes of the seventh row was similar. The ratio of Indo1 emissions was $0.35 \pm 0.09(n=13)$ and $0.32 \pm 0.18(n=13)$ for mechanical and ionomycin stimulations, respectively. This $\left[\mathrm{Ca}^{2+}\right]_{\mathrm{i}}$ level already was reached in cells of the third row after ionomycin focal application, $0.31 \pm 0.02(n=113)$ (Fig. $2 B$ ). Furthermore, $\mathrm{Ca}^{2+}$ responses monitored in astrocytes located at the limit of the intercellular calcium waves were, in most of the cases, all or none. Indeed, the variation of the ratio of Indo1 emissions was close to either 0.3 or zero, indicating that there was a threshold in $\mathrm{Ca}^{2+}$ responses. Interestingly, speeds of propagation measured between cells of the first and second rows, the second and the third rows, or between the fifth and the sixth rows were in the same range. For instance, speeds calculated from five typical experiments performed with mechanical stimulation were not significantly different: $14 \pm 2 \mu \mathrm{m} / \mathrm{sec}(n=22), 18 \pm 4$ $\mu \mathrm{m} / \mathrm{sec}(n=21)$, and $13 \pm 3 \mu \mathrm{m} / \mathrm{sec}(n=9)$, respectively ( $p=$ 0.54 , ANOVA). Taken together, these observations indicate that in astrocytes the propagation of intercellular calcium waves involves a regenerative, rather than a simple passive, process.

The requirement of functional gap junctions for intercellular calcium signaling between cultured astrocytes was confirmed in this study with the uncoupling agent $18-\alpha$-glycyrrhetinic acid ( $\alpha$ $\mathrm{GA} ; 10 \mu \mathrm{M})($ Fig. $1 B$ ). In the presence of this compound, the number of surrounding cells responding to mechanical and ionomycin stimulations was reduced drastically ( 4 and 2 cells, respectively), whereas the amplitude of the $\left[\mathrm{Ca}^{2+}\right]_{i}$ responses evoked in the stimulated cell was not affected (Table 1, Fig. 3).

After mechanical stimulation, the increase in $\left[\mathrm{Ca}^{2+}\right]_{\mathrm{i}}$ in the stimulated cell was attributable to an influx of $\mathrm{Ca}^{2+}$. Indeed, mechanical stimulation failed to induce a $\mathrm{Ca}^{2+}$ response in stimulated and surrounding cells $(n=14)$ when performed during the first 5 min of superfusion with a $\mathrm{Ca}^{2+}$-free solution containing 2 mm EGTA. This lack of response was not attributable to a depletion of internal calcium stores, because tests of their filling levels with ionomycin $(20 \mu \mathrm{M})$ at different times after superfusion with the $\mathrm{Ca}^{2+}$-free solution indicated that depletion started after $5 \mathrm{~min}$ and was completed after $10 \mathrm{~min}$ (Fig. 4). Moreover, the absence of response was not attributable to a block of the perme- 

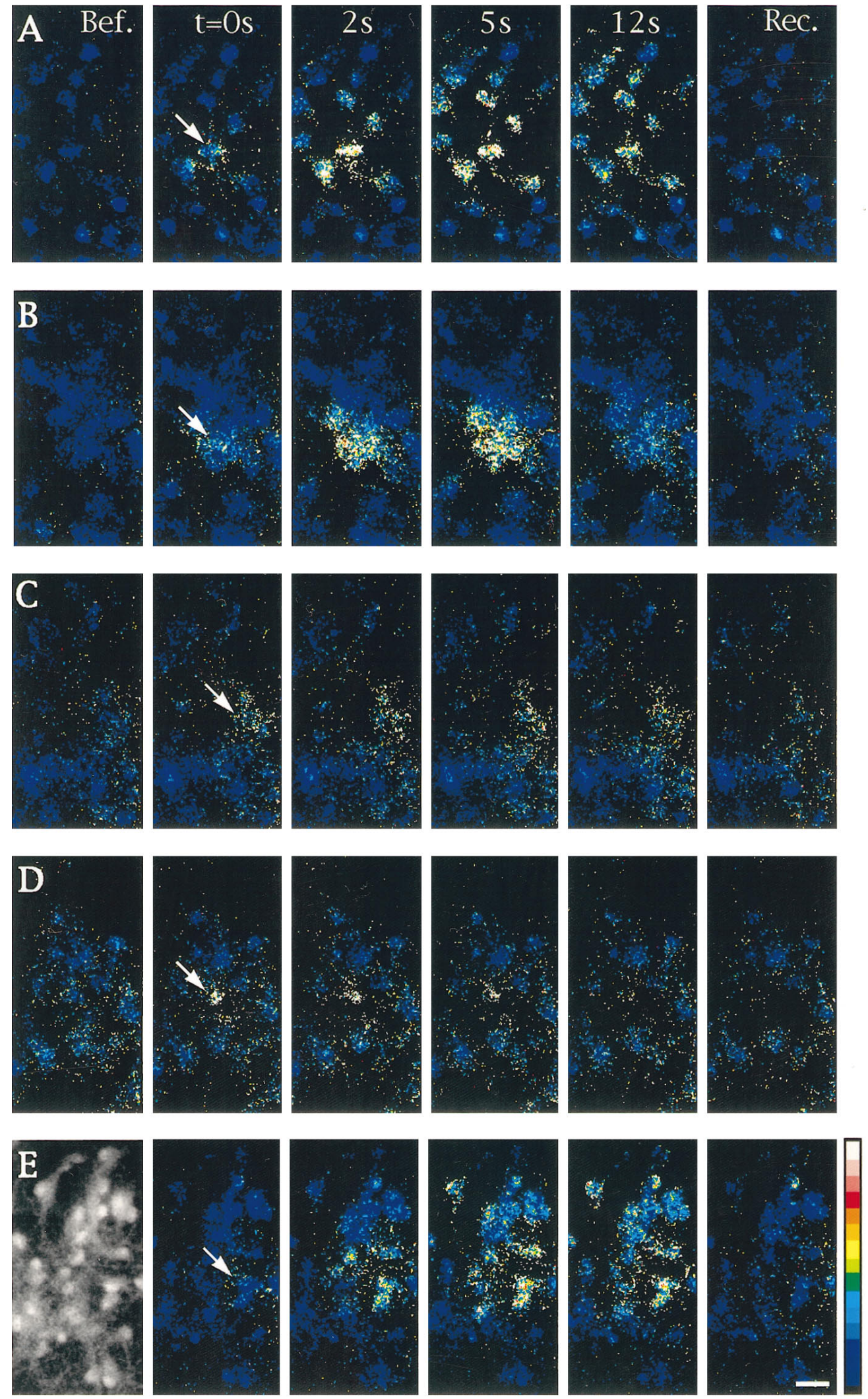

ability of gap junction channels, because exposure for $10 \mathrm{~min}$ of confluent astrocytes with a $\mathrm{Ca}^{2+}$-free solution containing $2 \mathrm{~mm}$ EGTA did not affect intercellular dye diffusion significantly (Giaume et al., 1992).

\section{PLC activation is a necessary step for regenerative intercellular calcium signaling in astrocytes}

Because in airway epithelial cells intercellular calcium signaling involves $\mathrm{IP}_{3}$ receptors (Boitano et al., 1992) and PLC activation 


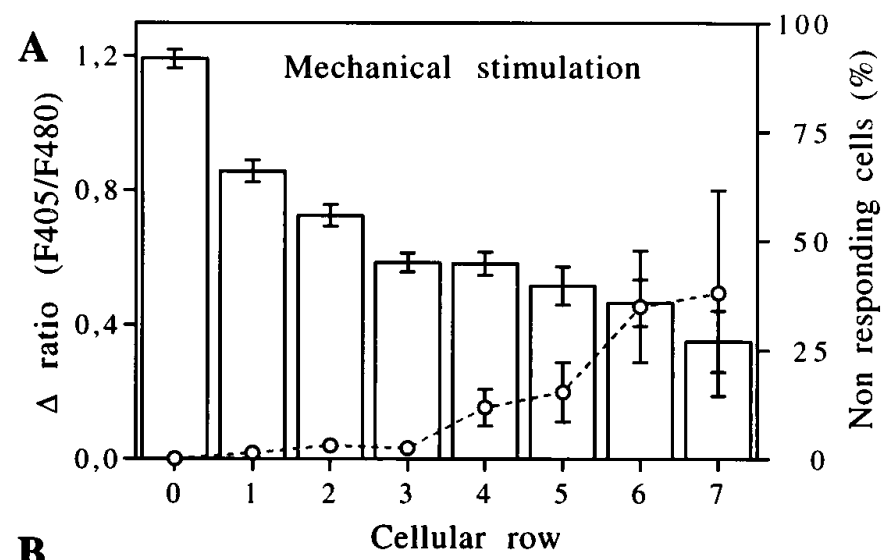

B

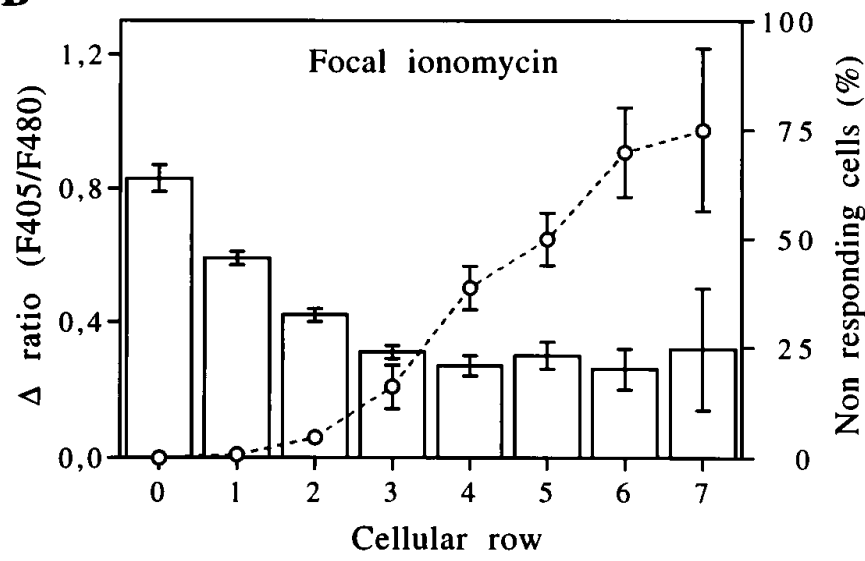

Figure 2. Quantification of amplitude of intercellular calcium signals and extent in cultured astrocytes. Analysis of intercellular calcium signaling generated $(A)$ by mechanical stimulation $(n=12)$ and $(B)$ by focal application of ionomycin $(n=21)$. Relative amplitude of $\left[\mathrm{Ca}^{2+}\right]_{\mathrm{i}}$ increases (left scales, open columns) and number of unresponsive cells (right scales, dashed line) were plotted by identifying the cellular row from which they were recorded. Cells were classified according to their location in reference to the stimulated cell, numbered 0 . Typically, stimulation was performed in the center of a microscopic field composed of $\sim 30$ cells forming approximately six to seven cellular rows. As the distance from the stimulated cell increased, the amplitude of the response decreased, and more cells did not respond. For both modes of stimulation, the extent of intercellular calcium signaling generally exceeded the investigated cell population.

(Hansen et al., 1995), it is possible that a calcium-dependent activation of PLC leading to the production of $\mathrm{IP}_{3}$ also could participate in the initiation and propagation of intercellular calcium waves in astrocytes. To test this hypothesis, we used the PLC inhibitor U-73122 and its inactive analog U-73343 (Smith et al., 1990; Bender et al., 1993) in cultured astrocytes. Incubation of astrocytes either with a low dose of ionomycin $(5 \mu \mathrm{M}, 5 \mathrm{~min})$ or with endothelin-1 (Et-1; $0.1 \mu \mathrm{M}, 10 \mathrm{~min})$, a potent activator of PLC (Marin et al., 1991), increased the accumulation of inositol phosphate (IP) derivatives, an index of PLC activity. In the presence of U-73122 (5 $\mu \mathrm{M})$, the ionomycin- and Et-1-induced accumulation of IPs was reduced significantly, whereas U-73343 (5 $\mu \mathrm{M}$ ) was ineffective (Fig. $5 A, B$ ).

When intercellular calcium signaling was tested after treatment of astrocytes with U-73122 (5 $\mu \mathrm{M}, 10$ to $60 \mathrm{~min})$, there was a clear reduction in the number of cells responding to either mechanical stimulation or to focal applications of ionomycin (Figs. $1 C, 3 B$, Table 1). The initial $\left[\mathrm{Ca}^{2+}\right]_{\mathrm{i}}$ increases in the stimulated cells were reduced slightly for both types of stimulation, suggesting that
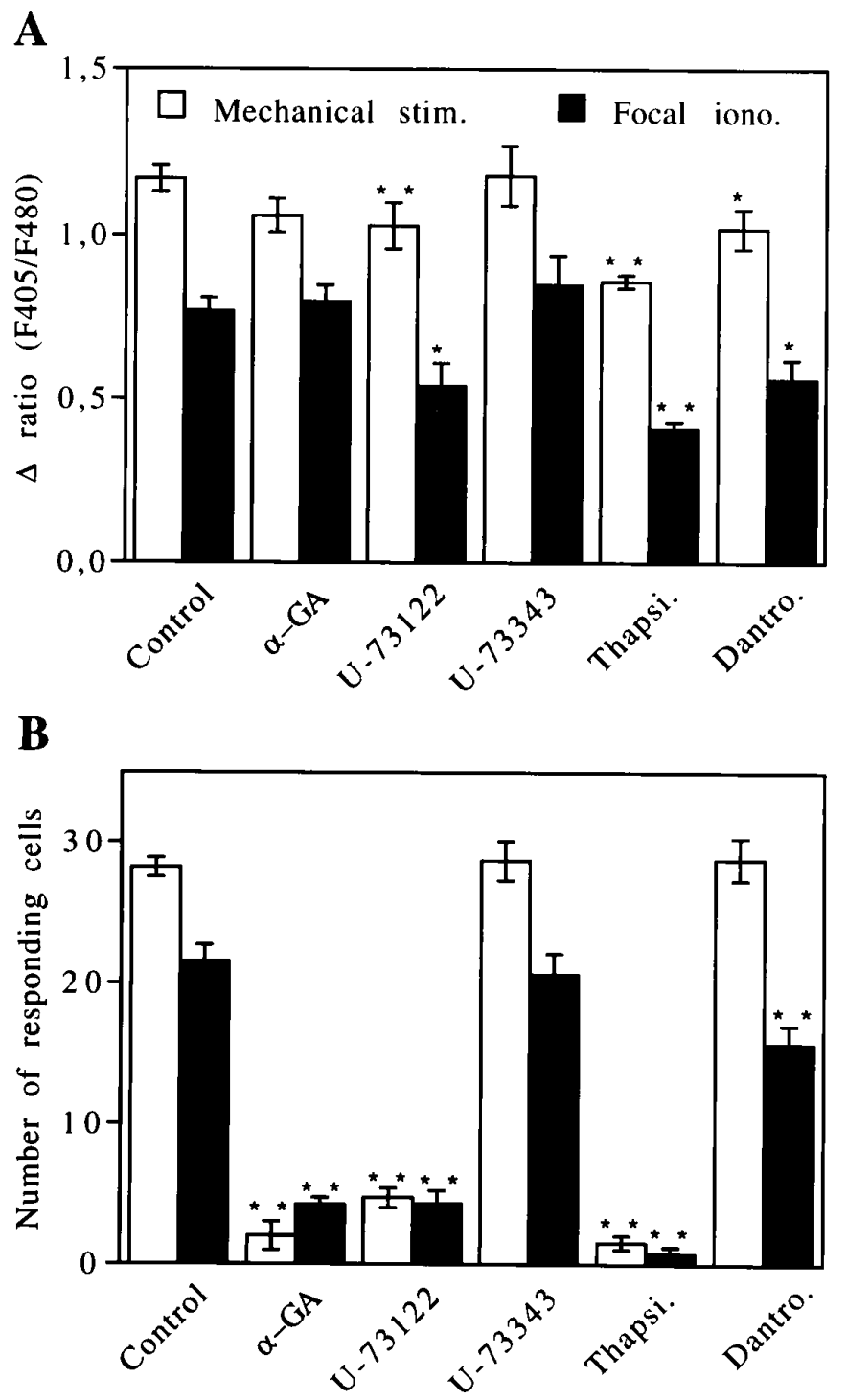

Figure 3. Regulation of intercellular calcium signaling propagation in cultured astrocytes. Different treatments were performed to identify the intra- and intercellular steps involved in calcium waves. Effects of the uncoupling agent $18 \alpha-G A(10 \mu \mathrm{M})$, the PLC inhibitor U73122 (5 $\mu \mathrm{M})$, and its inactive analog $U 73343(5 \mu \mathrm{M})$ were tested separately. Participation of the two main sources of intracellular $\mathrm{Ca}^{2+}$ fast mobilization also was investigated by using thapsigargin (Thapsi.; $2 \mu \mathrm{M}$ ) and dantrolene (Dantro.; $10 \mu \mathrm{M}$ ). Intercellular calcium waves were generated either by mechanical stimulation (open columns) or by focal application of ionomycin ( filled columns). Two parameters were considered in this analysis: $(A)$ the amplitude of the $\mathrm{Ca}^{2+}$ response in the stimulated cell and $(B)$ the number of responding cells in the field that account for the extent of intercellular calcium signaling. Averaged values were obtained from independent experiments, with an $n$ ranging from 5 to 54. Statistical analysis was conducted by one-way ANOVA, followed by post hoc Dunnett's multiple comparisons test. Significance was established at ${ }^{*} p<0.05$ and ${ }^{*} p<0.01$.

$\mathrm{Ca}^{2+}$ entry after both modes of stimulation activates PLC in the target cells. However, this effect of U73122 did not account for the lack of intercellular calcium signaling, because initial $\left[\mathrm{Ca}^{2+}\right]_{\mathrm{i}}$ increases were still higher than those recorded in cells of the first cellular row when intercellular calcium signals propagated to at least six rows in the control condition (Fig. 2). Finally, the U-73122-induced blockage of intercellular calcium waves did not 


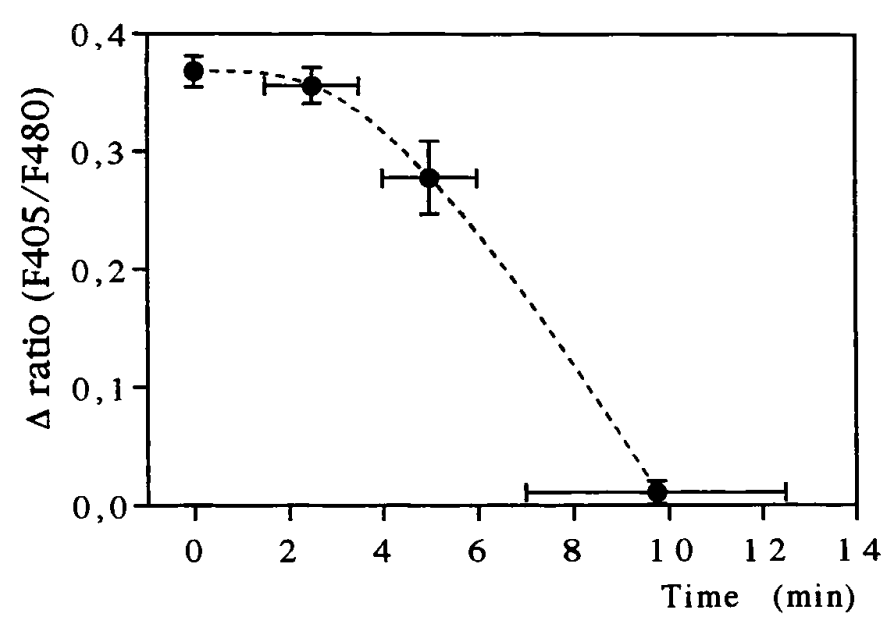

Figure 4. Depletion of internal $\mathrm{Ca}^{2+}$ stores after exposure of astrocytes to an external calcium-free solution. The effect of a calcium-free external solution containing EGTA $(2 \mathrm{mM})$ on the filling of internal $\mathrm{Ca}^{2+}$ stores was tested by using $30-60 \mathrm{sec}$ applications of ionomycin $(20 \mu \mathrm{M})$. At the beginning of the perfusion, ionomycin indicated the amount of filling of the internal stores in control conditions. With time, $\mathrm{Ca}^{2+}$ pools were reduced progressively by the lack of external $\mathrm{Ca}^{2+}$ and were emptied completely after $10 \mathrm{~min}$. Note that depletion of internal $\mathrm{Ca}^{2+}$ stores started after 5 min of treatment. Data are pooled from 25 experiments in which each measurement was performed independently on seven different cells.

result from a decrease in the permeability of gap junction channels, because this PLC inhibitor was without effect on intercellular dye diffusion (Table 1). As expected, the inactive compound $\mathrm{U}-73343$ affected neither the number nor the shape of $\mathrm{Ca}^{2+}$ responses nor the speed of intercellular calcium signaling propagation (Fig. $3 A, B$, Table 1).

Altogether, these data indicate that PLC activity is required for the propagation of regenerative calcium waves in astrocyte networks, suggesting that $\mathrm{IP}_{3}$ could participate in this process because its production results mainly from the activation of this enzyme. Recently, it was reported that, in addition to PLC inhibition, U-73122 depletes internal $\mathrm{Ca}^{2+}$ stores (Jin et al., 1994; Willems et al., 1994). Although this has to be confirmed in astrocytes, such a side effect of U-73122 does not rule out the role of PLC and $\mathrm{IP}_{3}$ in intercellular calcium signaling.

The involvement of internal calcium stores in intercellular calcium signaling was studied by using thapsigargin and dantrolene, which are inhibitors of the $\mathrm{Ca}^{2+}$ ATPase from the endoplasmic reticulum and of the $\mathrm{Ca}^{2+}$-induced $\mathrm{Ca}^{2+}$ release, respectively. As previously reported (Charles et al., 1993), pretreatment with thapsigargin $(2 \mu \mathrm{M}, 5 \mathrm{~min})$ completely inhibited intercellular calcium signaling, whereas dantrolene treatment $(10 \mu \mathrm{M}, 10 \mathrm{~min})$ had no significant effect on the extent and speed of propagation of intercellular calcium waves (Figs. $1 D, E, 3 B$, Table 1). Both of these treatments were followed by a slight reduction in amplitude of the $\mathrm{Ca}^{2+}$ response in the stimulated cells (Fig. $3 A$ ). However, by themselves these decreases cannot account for the blockage of intercellular calcium signaling by thapsigargin. Finally, scrapeloading experiments indicated that, under the conditions used, these compounds did not affect junctional permeability (Table 1).

\section{Exogenous factors are not implicated in intercellular calcium signaling between rat astrocytes}

As already indicated, functional gap junction channels are required for intercellular calcium signaling in astrocytes. However, alternate mechanisms also could be involved in this process, as, for example a calcium-dependent release in the extracellular space of an active factor, which, in turn, could stimulate membrane receptors of astrocytes. Such a mechanism, which has been described in mast cells (Osipchuk and Cahalan, 1992) and mammary gland cells (Enomoto et al., 1992), cannot be excluded as operating between astrocytes. In fact, these cells have the capacity to release ATP (Bruner et al., 1993) and glutamate (Parpura et al., 1994) and express purinergic and glutamatergic membrane receptors linked to PLC (Stella et al., 1994) and glutamatergic ionotropic receptors (Finkbeiner, 1995).

Extracellular ATP was eliminated enzymatically by using an ATP-degrading enzyme, apyrase $(2 \mathrm{U} / \mathrm{ml})$, a procedure that prevents ATP receptor-mediated release of arachidonic acid in astrocytes (N. Stella, unpublished results). This treatment modified neither the extent nor the speed of intercellular calcium waves induced by mechanical stimulation but significantly reduced the ratio of cells of the first row (Table 2). Rather than an effect of ATP, this reduction was attributed to the effect of apyrase treatment itself, which at such a concentration was found to affect the permeability of gap junctions (Table 2). Glutamate pyruvate transaminase $(4 \mathrm{U} / \mathrm{ml})$, an enzyme that degrades glutamate when used in combination with pyruvate $(2 \mathrm{~mm})$, also led to a potent inhibition of the permeability of gap junction channels and could not be used to test the involvement of glutamate release in intercellular calcium signaling. Alternatively, $\mathrm{L}_{-} \mathrm{AP}_{3}(1 \mathrm{~mm})$ and DNQX (0.1 mM), antagonists of glutamate metabotropic and AMPA-kainate ionotropic receptors in astrocytes (Stella et al., 1994), were applied. In the presence of these two compounds, no alteration of intercellular calcium wave propagation induced by mechanical stimulation was recorded (Table 2).

However, the participation of external ATP and/or glutamate in intercellular calcium signaling could have been masked by important intercellular communication because of open gap junction channels. Such a possibility was excluded by testing the effect of apyrase and $\mathrm{L}_{-} \mathrm{AP}_{3}$ plus DNQX when gap junction channels were closed by $18 \alpha-\mathrm{GA}$, because the number of cells responding to mechanical stimulation was similar with or without these treatments (Table 2).

Finally, a contribution of voltage-dependent $\mathrm{Ca}^{2+}$ channels in intercellular calcium signaling was excluded. First, superfusion of astrocytes with a high $\mathrm{KCl}$ solution $(50 \mathrm{~mm})$ did not increase significantly $\left[\mathrm{Ca}^{2+}\right]_{\mathrm{i}}(\Delta$ ratio $=0.031 \pm 0.007 ; n=77)$. Moreover, substitution of $\mathrm{Ca}^{2+}$ by cadmium $(250 \mu \mathrm{M})$, a blocking agent of voltage-dependent calcium channels, affected neither the extent nor the speed of propagation of intercellular calcium signaling (Table 2).

\section{Receptor-induced intercellular calcium signaling}

Detailed analysis of the $\mathrm{Ca}^{2+}$ responses to ionomycin application indicated a variability in the amplitude of the $\left[\mathrm{Ca}^{2+}\right]_{i}$ increase induced by the ionophore in the astrocyte stimulated initially. Interestingly, a correlation was found between the amplitude of this initial $\mathrm{Ca}^{2+}$ response and the number of cells involved in calcium waves, suggesting that the extent of intercellular calcium signals may depend on the stimulus strength triggering the propagation of the waves (Fig. $7 A$, top diagram). However, in addition to a large influx of $\mathrm{Ca}^{2+}$ and a partial depletion of internal $\mathrm{Ca}^{2+}$ stores because of its ionophore property, ionomycin stimulation was associated with an activation of PLC in the stimulated cell, as indicated by a reduced amplitude of the $\mathrm{Ca}^{2+}$ response after treatment with U-73122 (Fig. 3A). This observation was confirmed 
A

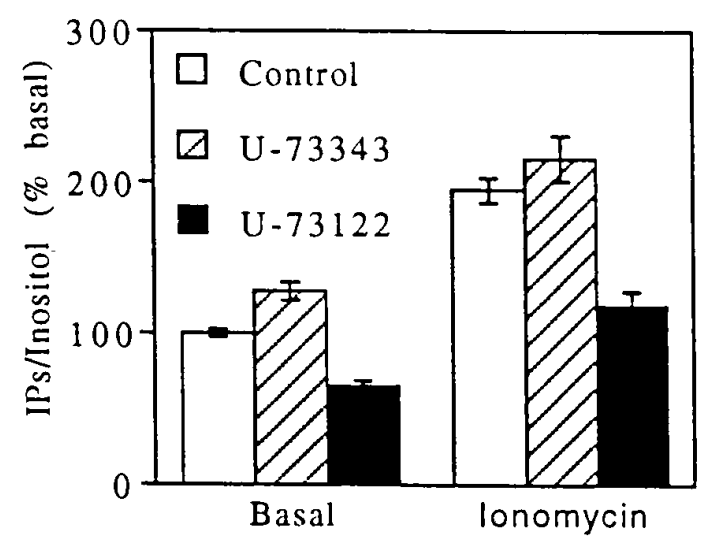

C

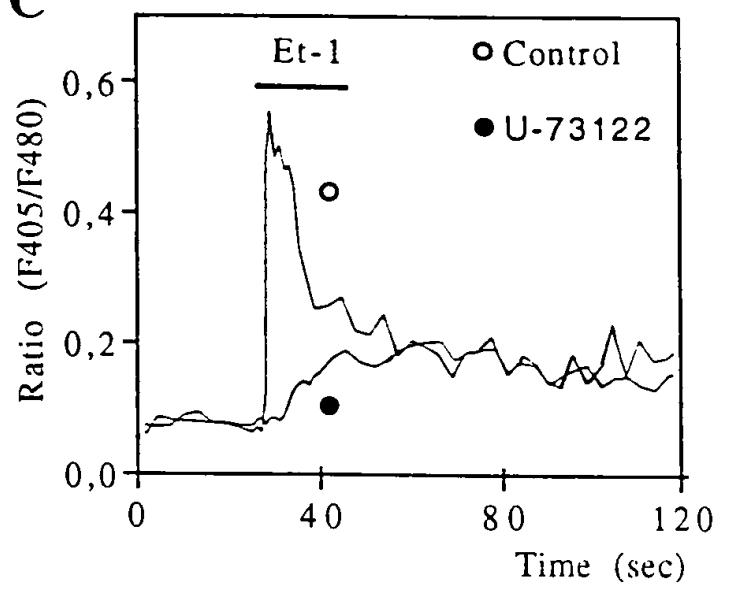

B

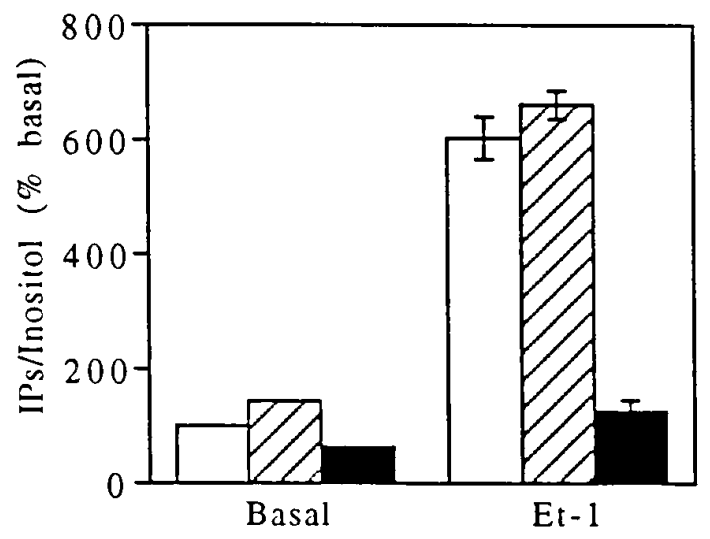

D

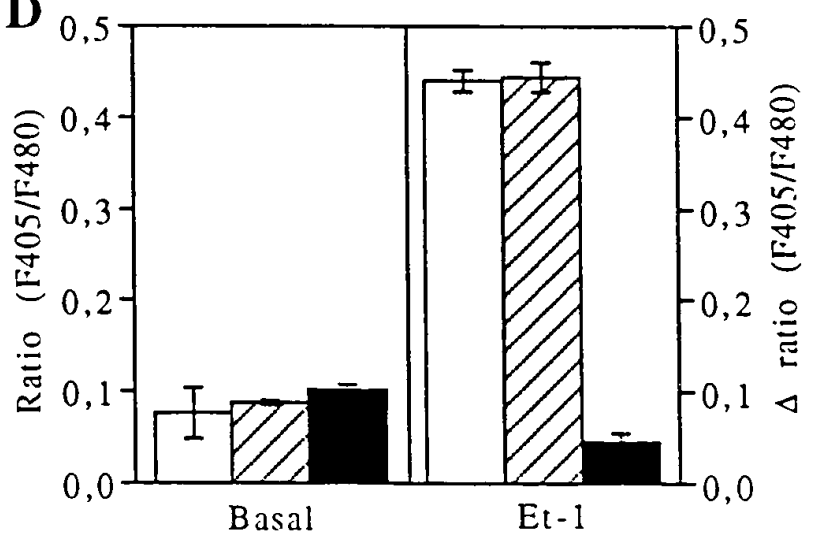

Figure 5. Inhibition by $\mathrm{U}-73122$ of inositol phosphate formation and calcium responses in cultured astrocytes. $A$, $B$, Biochemical assays of inositol phosphates (IPs) derived from formation induced by $(A)$ ionomycin $(5 \mu \mathrm{M}, 5 \mathrm{~min})$ and $(B)$ Et-1 $(0.1 \mu \mathrm{M}, 10 \mathrm{~min})$. Data are shown under control conditions (open columns) in the presence $(5 \mu \mathrm{M}, 10$ min preincubations) of the PLC inhibitor U-73122 (filled columns) and of its inactive analog U-73343 (dashed columns). C, Typical $\mathrm{Ca}^{2+}$ responses recorded in astrocytes perfused with Et-1 $(0.1 \mu \mathrm{M}, 10 \mathrm{sec})$ under control conditions (open circle) and with U-73122 (5 $\mu \mathrm{M}$; filled circle). Note that, in the presence of the PLC inhibitor, the initial peak is suppressed, whereas the plateau is conserved. Each trace is averaged from seven astrocytes recorded in the same microscopic field. D, Effect of $5 \mu \mathrm{M}$ U-73122 ( filled columns) and $\mathrm{U}-73343$ (dashed columns) on basal $\left[\mathrm{Ca}^{2+}\right]_{\mathrm{i}}$ (left scale) and on the relative amplitude of $\mathrm{Ca}^{2+}$ peak induced by Et-1 perfusion (right scale). Data are averaged from 243 cells in control, 160 cells with U-73122, and 106 cells with its inactive form.

by biochemical assays indicating that ionomycin $(5 \mu \mathrm{M}, 5 \mathrm{~min})$ increased the formation of inositol phosphates (Fig. $5 A$ ). Consequently, with the use of focal application of ionomycin to generate intercellular calcium signals, it was difficult to identify the critical intracellular event $\left(\mathrm{Ca}^{2+}\right.$ entry or PLC activity) that triggers and sets the extent of intercellular calcium waves.

Astrocytes are targets for numerous neurotransmitters and peptides that produce receptor-mediated $\left[\mathrm{Ca}^{2+}\right]_{i}$ elevation via the activation of PLC. These compounds differ by their potency to stimulate PLC activity and to produce $\mathrm{IP}_{3}$-induced $\mathrm{Ca}^{2+}$ responses (Finkbeiner, 1993). Accordingly, the ability of Et-1, glutamate, and $\alpha 1$-adrenergic and muscarinic agonists (methoxamine and carbachol, respectively) to stimulate PLC and to induce intercellular calcium waves were compared to study the relation between the level of PLC activation and the initiation of intercellular calcium signaling.

Biochemical assays indicated that in cultured rat astrocytes both carbachol $(3 \mathrm{~mm})$ and methoxamine $(0.1 \mathrm{~mm})$ slightly stimulated IPs accumulation ( $31 \pm 7 \%$ and $70 \pm 7 \%, n=3$, respectively), whereas glutamate $(0.1 \mathrm{~mm})$ and Et-1 $(0.1 \mu \mathrm{M})$ were more potent (328 $\pm 39 \%, n=3$ and $569 \pm 59 \%, n=6$, respectively). As expected, these biochemical responses were blocked by U-73122 (5 $\mu \mathrm{M}, 10 \mathrm{~min}$ ). For example, Et-1-induced IPs accumulation was reduced completely by the PLC inhibitor (Fig. $5 B$ ). When used on the Et-1-induced $\mathrm{Ca}^{2+}$ response, U-73122 selectively inhibited the initial $\mathrm{Ca}^{2+}$ peak without affecting the plateau (Fig. 5C,D) known to be attributable to a $\mathrm{Ca}^{2+}$ influx (Marin et al., 1991). These observations indicated that the initial $\left[\mathrm{Ca}^{2+}\right]_{\mathrm{i}}$ increase was attributable to the production of $\mathrm{IP}_{3}$ by PLC and that the amplitude of this $\mathrm{Ca}^{2+}$ peak could be taken as an index for the activity of the enzyme.

In agreement with the biochemical assays, focal application of muscarinic and adrenergic agonists produced weak elevations in $\left[\mathrm{Ca}^{2+}\right]_{\mathrm{i}}$ in the stimulated cells. Interestingly, the amplitude of these $\mathrm{Ca}^{2+}$ responses was always below a relative ratio of Indo1 emissions of 0.3 (Fig. 7B, horizontal dashed line), and they always failed to induce calcium waves $(n=42$ and $n=$ 35 , respectively). Indeed, focal application of these compounds 
Table 2. Effects of extracellular ATP or glutamate and voltage-dependent $\mathrm{Ca}^{2+}$ channels on the properties of intercellular calcium signaling and gap junction permeability

\begin{tabular}{|c|c|c|c|c|c|c|}
\hline Experimental conditions & $\begin{array}{l}\text { Number of } \\
\text { cells in the } \\
\text { field (no. of } \\
\text { experiments) }\end{array}$ & $\begin{array}{l}\text { Number of } \\
\text { responding cells } \\
(\%)\end{array}$ & $\begin{array}{l}\text { Ratio }(F 405 / F 480) \\
\text { of stimulated cell } \\
\text { (no. of cells) }\end{array}$ & $\begin{array}{l}\text { Ratio }(F 405 / F 480) \\
\text { of the cells of the } \\
\text { first row } \\
\text { (no. of cells) }\end{array}$ & $\begin{array}{l}\text { Velocity of } \\
\text { ICW } \\
(\mu \mathrm{m} / \mathrm{sec}) \\
(\text { no. of cells })\end{array}$ & $\begin{array}{l}\text { Scrape- } \\
\text { loading }(\%)\end{array}$ \\
\hline Control & $34 \pm 1(54)$ & $28 \pm 1(84)$ & $1.17 \pm 0.02(55)$ & $0.81 \pm 0.02(336)$ & $16 \pm 0.7(62)$ & $\begin{array}{l}100^{\mathrm{A}} \\
100^{\mathrm{B}}\end{array}$ \\
\hline Apyrase $2 \mathrm{U} / \mathrm{ml}$ & $32 \pm 1(10)$ & $26 \pm 2(81)$ & $1.13 \pm 0.03(10)$ & $0.56 \pm 0.03(62)$ & $14 \pm 0.8(34)$ & $\begin{array}{c}104 \pm 12^{\mathrm{A}}(6) \\
50 \pm 29^{\mathrm{C}}(3) \\
24 \pm 6^{\mathrm{B}}(3)\end{array}$ \\
\hline $\begin{array}{l}\text { Apyrase } 2 \mathrm{U} / \mathrm{ml} \\
\quad+18 \alpha \text {-glycyrrhetinic acid } 10 \mu \mathrm{M}\end{array}$ & $34 \pm 1(9)$ & $3 \pm 1(9)$ & $1.01 \pm 0.05(14)$ & $0.40 \pm 0.11(6)$ & - & - \\
\hline $\mathrm{L}-\mathrm{AP}_{3} 1 \mathrm{mM}+\mathrm{DNQX} 0.1 \mathrm{~mm}$ & $38 \pm 1(14)$ & $29 \pm 2(75)$ & $1.13 \pm 0.03(14)$ & $0.67 \pm 0.04(79)$ & $18 \pm 0.8(70)$ & $\begin{array}{l}90 \pm 10^{\mathrm{A}}(3) \\
91 \pm 10^{\mathrm{B}}(3)\end{array}$ \\
\hline $\begin{array}{l}\mathrm{L}_{-} \mathrm{AP}_{3} 1 \mathrm{mM}+\text { DNQX } 0.1 \mathrm{mM} \\
\quad+18 \alpha \text {-glycyrrhetinic acid } 10 \mu \mathrm{M}\end{array}$ & $35 \pm 1(10)$ & $4 \pm 1(13)$ & $1.09 \pm 0.05(12)$ & $0.35 \pm 0.04(26)$ & - & - \\
\hline Cadmium $250 \mu \mathrm{M}$ & $35 \pm 3(6)$ & $29 \pm 2(81)$ & $1.17 \pm 0.03(7)$ & $0.97 \pm 0.05(31)$ & $17.8 \pm 0.5(53)$ & - \\
\hline
\end{tabular}

In scrape-loading experiments A, B, and C indicate that time of application was 10, 30, and 60 min, respectively.

resulted in a very limited number of cells $(<4)$ exhibiting $\mathrm{Ca}^{2+}$ increase around the stimulated astrocyte. Further, the amplitude of these responses was very low (Fig. 6C). In contrast, focal application of glutamate $(0.1 \mathrm{mM})$ and Et-1 $(0.1 \mu \mathrm{M})$ evoked large increases in $\left[\mathrm{Ca}^{2+}\right]_{\mathrm{i}}$ in the target cells and induced regenerative intercellular calcium waves (Figs. 6A, $B, 7 B$ ). Quantitative analysis of Et-1 responses also demonstrated a linear relationship between the $\left[\mathrm{Ca}^{2+}\right]_{\mathrm{i}}$ rise in the stimulated cell and the extent of intercellular calcium signaling (Fig. $7 A$, bottom diagram). Because the amplitude of the initial calcium response can be taken as an index of PLC activity, this observation suggests a correlation between the receptor-mediated production of $\mathrm{IP}_{3}$ and the extent of intercellular calcium signaling. The speed of calcium wave propagation induced by focal application of either glutamate or Et-1 was in the same range $(15 \pm 1 \mu \mathrm{m} / \mathrm{sec}, n=28$ and $14 \pm 1 \mu \mathrm{m} / \mathrm{sec}, n=27$, respectively) as those estimated for mechanical or focal ionomycin stimulation (see Table 1). Although the propagation of intercellular calcium signals occurred in all directions when astrocytes were stimulated mechanically or by ionomycin (Fig. $1 A$ ), focal application of either glutamate or Et-1 was characterized by more complex pathways, suggesting that some directions in calcium wave propagation were favored (Fig. 6A). As already shown for glutamate (Venance et al., 1995), inhibition of gap junction channels with $18 \alpha$-GA $(10 \mu \mathrm{M})$ blocked the propagation of intercellular calcium signaling induced by focal application of Et-1 or ionomycin (Figs. $6 A, 7 A, B$ ), while the initial increase in $\left[\mathrm{Ca}^{2+}\right]_{\mathrm{i}}$ was not altered. In both cases, $\mathrm{Ca}^{2+}$ responses were restricted to the same cellular areas as with methoxamine or carbachol application (Fig. 7B), which confirmed the absence of regenerative intercellular calcium waves when these two agonists are applied locally.

\section{DISCUSSION}

The aim of this study was to identify the intra- and intercellular events involved in intercellular calcium signaling between cultured rat astrocytes. Two main steps were distinguished in this analysis: the initiation phase in a single stimulated cell and the propagation of calcium signals through astrocytic networks. This question was addressed by taking advantage of different stimula- tion protocols to generate intercellular calcium signals. The mechanism of propagation was studied by generating large and transient $\left[\mathrm{Ca}^{2+}\right]_{\mathrm{i}}$ elevations in a selected astrocyte. Both mechanical and ionomycin stimulations markedly increased $\left[\mathrm{Ca}^{2+}\right]_{i}$ in the targeted cell and were followed by concentric propagation of intercellular calcium signals. These two modes of stimulation induced $\left[\mathrm{Ca}^{2+}\right]_{\mathrm{i}}$ elevations in the stimulated cells, which resulted partly from a $\mathrm{Ca}^{2+}$ influx. This is apparent because, with mechanical stimulation, no significant rise in $\left[\mathrm{Ca}^{2+}\right]_{\mathrm{i}}$ was observed in the absence of extracellular $\mathrm{Ca}^{2+}$, and ionomycin is well known to act as a $\mathrm{Ca}^{2+}$ ionophore. However, a limited but significant reduction of the $\mathrm{Ca}^{2+}$ responses was observed in stimulated cells pretreated with either PLC inhibitor U-73122 or with compounds that affected internal $\mathrm{Ca}^{2+}$ stores. The initiation phase was investigated with single-cell pharmacological stimulation induced by focal application of several receptor agonists known to produce different levels of PLC activation.

Treatment of astrocytes with U-73122 or thapsigargin prevented intercellular calcium signals, whereas dantrolene had no effect. As previously reported (Charles et al., 1993), the experiments with compounds that affect the release of $\mathrm{Ca}^{2+}$ from internal stores suggest that a $\mathrm{Ca}^{2+}$-induced $\mathrm{Ca}^{2+}$ release mechanism does not participate in intercellular calcium signaling, whereas $\mathrm{IP}_{3}$-induced $\mathrm{Ca}^{2+}$ release seems more likely to be involved. Inhibition of PLC activity, which represents the main source of $\mathrm{IP}_{3}$ production, reinforces this statement, because it indicates that activation of this enzyme is required for the propagation of intercellular calcium waves in astrocytes. Functional gap junction channels are also necessary for the propagation of intercellular calcium signaling in astrocytes (Charles et al., 1992; Finkbeiner, 1992; Venance et al., 1995). Although junctional permeability for $\mathrm{IP}_{3}$ has not yet been tested in these cells, gap junction channels composed of connexin 43, the main junctional protein in astrocytes (Dermietzel et al., 1991; Giaume et al., 1991a), have been reported to be permeable to $\mathrm{IP}_{3}$ in aortic endothelial cells (Carter et al., 1994). In addition, the range of diffusion and lifetime of $\mathrm{IP}_{3}$ in cytoplasm are much higher than that of ionized $\mathrm{Ca}^{2+}$ (Allbritton et al., 1992). Thus, $\mathrm{IP}_{3}$ could represent the signaling molecule that plays a major role in the 

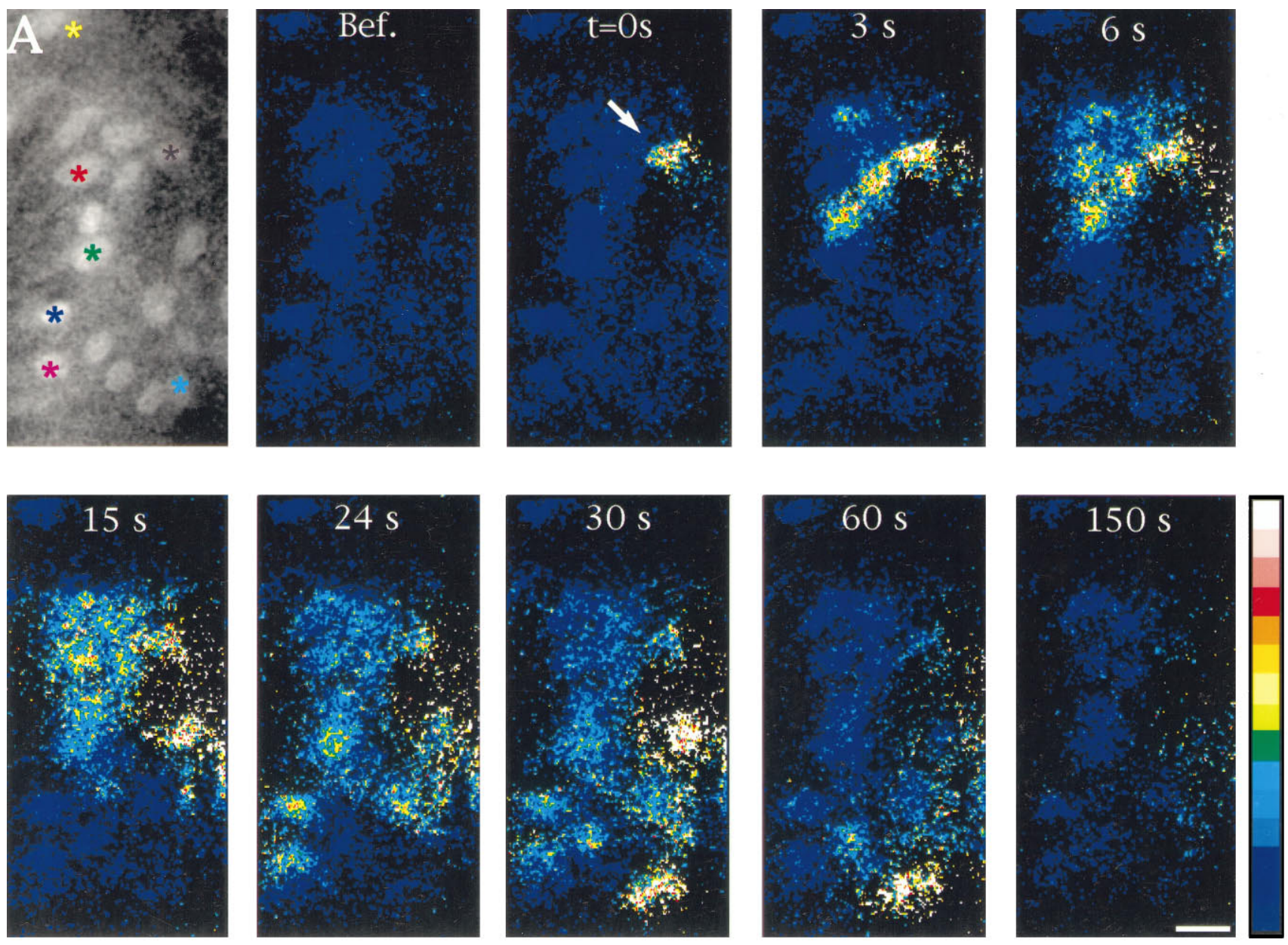

\section{B}
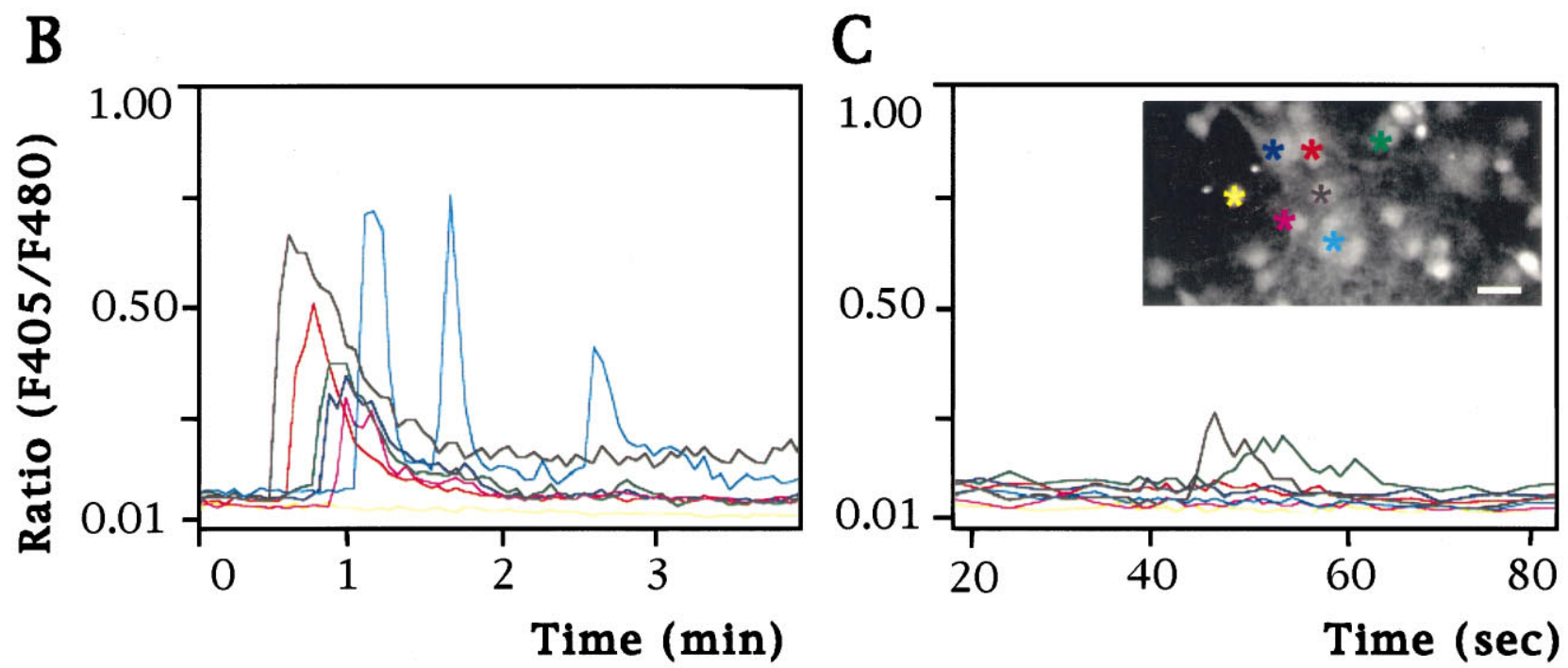

Figure 6. Distribution and pattern of $\left[\mathrm{Ca}^{2+}\right]_{\mathrm{i}}$ responses to focal applications of receptor agonists. $A$, Pseudocolor sequence of images showing $\left[\mathrm{Ca}^{2+}\right]_{\mathrm{i}}$ changes in a population of astrocytes loaded with Indo1-AM and stimulated by a focal application (arrow) of Et-1 (0.1 $\mu \mathrm{M})$. Times after Et-1 application are indicated in the top part of each image. A fluorescent image obtained from emission at $480 \mathrm{~nm}$ indicates the location of the cells in the investigated field. Calibration bar, $25 \mu \mathrm{m}$. B, Quantification of $\left[\mathrm{Ca}^{2+}\right]_{\mathrm{i}}$ responses in several neighboring astrocytes after the focal application of Et-1, as illustrated in $A$. The colors of the lines in the graph correspond to the cells identified in the top left images by asterisks of the same color. Note that the upper astrocytes (yellow) did not show a $\left[\mathrm{Ca}^{2+}\right]_{\mathrm{i}}$ response, indicating that intercellular calcium signaling did not occur in this direction. $C$, Pattern of $\left[\mathrm{Ca}{ }^{2+}\right]_{\mathrm{i}}$ changes after a focal application of methoxamine $(0.1 \mathrm{mM})$. Note that the amplitude of the stimulated cell is much lower than with Et-1 and that only one adjacent cell responded at a delayed time. Inset, Fluorescent image at $480 \mathrm{~nm}$ emission of the investigated field. Colored asterisks indicate cells from which measurements of $\left[\mathrm{Ca}^{2+}\right]_{i}$ were performed and plotted on the graph. Calibration bar, $25 \mu \mathrm{m}$. 
$\mathbf{A}$

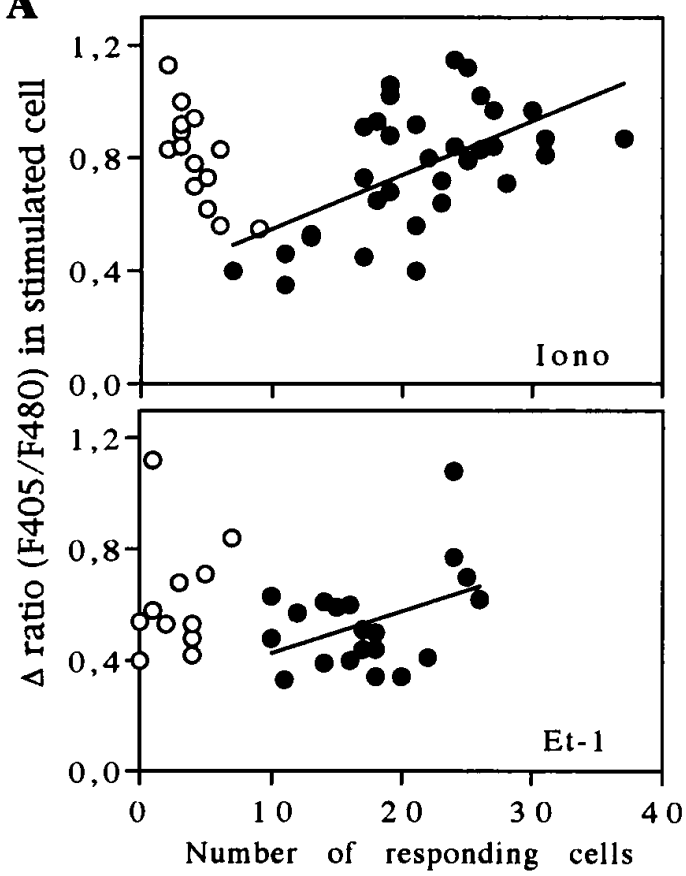

B

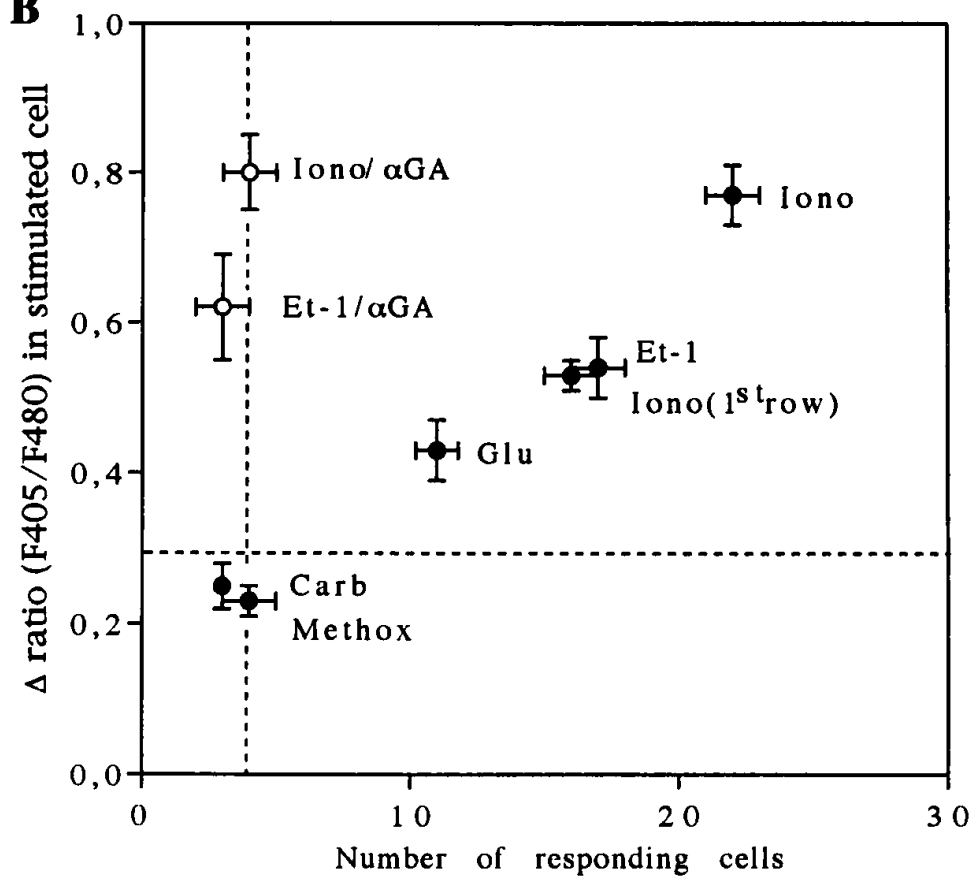

Figure 7. Relationship between the amplitude of $\left[\mathrm{Ca}^{2+}\right]_{\mathrm{i}}$ increases induced by pharmacological stimulation and the extent of intercellular calcium signaling. A, Top diagram, Plot of $\left[\mathrm{Ca}^{2+}\right]_{\mathrm{i}}$ changes generated by focal application of ionomycin $(50 \mu \mathrm{M})$ against the number of responding cells in the absence ( filled circles) and in the presence (open circles) of $18 \alpha-\mathrm{GA}(10 \mu \mathrm{M})$. In control conditions, the extent of the intercellular calcium signaling was correlated with the magnitude of the initial $\left[\mathrm{Ca}^{2+}\right]_{\mathrm{i}}$ response in the stimulated cells, as indicated by a linear regression fit. $A$, Bottom diagram, Plot of $\left[\mathrm{Ca}^{2+}\right]_{\mathrm{i}}$ changes evoked by focal application of Et-1 $(0.1 \mu \mathrm{M})$. Data were fit with the plot of a linear regression equation. $B$, Average plot of the extent of intercellular calcium signaling, indexed by the number of responding cells, against the amplitude of the $\left[\mathrm{Ca}{ }^{2+}\right]_{\mathrm{i}}$ response in the cells stimulated by specific pharmacological agents. Experiments performed with $18 \alpha$-GA $(10 \mu \mathrm{M})$ defined a restricted area in which no intercellular calcium signaling occurred (vertical dashed line). Note that in the presence of the uncoupling agent intercellular calcium signaling is blocked without any change in amplitude of the $\left[\mathrm{Ca}^{2+}\right]_{\mathrm{i}}$ response. With methoxamine (Methox) and carbachol (Carb), no intercellular calcium signaling was triggered, as indicated by the low number of responding cells, which is similar to that observed with endothelin-1 (Et-1) and ionomycin (Iono) when gap junctions are inhibited. With glutamate $(G l u)$, endothelin-1, and ionomycin focal applications, higher $\left[\mathrm{Ca}^{2+}\right]_{\mathrm{i}}$ responses in the stimulated cells were monitored, and intercellular calcium signals were recorded. For these three trials, the averaged initial $\left[\mathrm{Ca}^{2+}\right]_{\mathrm{i}}$ increase was greater than threshold values of $\sim 0.3$ (horizontal dashed line) to trigger intercellular calcium signaling. Note that, for experiments performed with ionomycin application, the number of responding cells also was plotted against the amplitude of $\left[\mathrm{Ca}^{2+}\right]_{\mathrm{i}}$ changes in cells of the first row. This corresponds exactly to the situation obtained with application of Et-1. Averaged data were obtained from a number of independent experiments ranging from 11 to 33 .

intercellular step of the propagation process, although this does not rule out the possibility that $\mathrm{Ca}^{2+}$ also could diffuse through gap junction channels.

The constant speed of propagation found between two proximal and two distal cells suggests that intercellular calcium signaling is not attributable to a simple intercellular passive diffusion of a signaling molecule but, rather, to a decremental regenerative process. This statement is supported by the existence of a threshold in the amplitude of the $\mathrm{Ca}^{2+}$ response monitored in cells located at the limit of the calcium wave. To provide a regenerative mechanism, we have to produce new $\mathrm{IP}_{3}$. The observed accumulation of IPs induced by ionomycin and its block by U-73122 indicate that a $\mathrm{Ca}^{2+}$-dependent activation of PLC occurs in astrocytes. Accordingly, intercellular calcium wave propagation in astrocytes could involve, successively, a $\mathrm{Ca}^{2+}$-dependent formation of $\mathrm{IP}_{3}$ in donor cells and an intercellular diffusion of $\mathrm{IP}_{3}$ (and/or $\mathrm{Ca}^{2+}$ ) through open gap junction channels, followed by an $\mathrm{IP}_{3}$-induced release of $\mathrm{Ca}^{2+}$ in adjacent receiving cells. This sequence of events is repeated as long as the amount of $\mathrm{IP}_{3}$ crossing gap junction channels is high enough to induce a rise in $\left[\mathrm{Ca}^{2+}\right]_{\mathrm{i}}$ capable of reaching a threshold level for PLC activation in receiving cells. Thus, this threshold level of $\left[\mathrm{Ca}^{2+}\right]_{i}$ represents a limiting factor that may account for the reduction in the number of responding cells with distance. The amount of $\mathrm{IP}_{3}$ produced by PLC also may be critical because in astrocytes a minimal concentration of $\mathrm{IP}_{3}$ has to be reached to evoke the release of $\mathrm{Ca}^{2+}$ from internal stores (Khodakhah and Ogden, 1993). These two limiting steps could explain why a plateau is reached when the amplitude of the $\mathrm{Ca}^{2+}$ response is plotted versus the cellular rows. Such an all-or-none responsiveness was particularly clear with ionomycin application, because the size of cellular field involving intercellular calcium signaling was smaller and allowed for monitoring a large number of nonresponding cells.

Alternative mechanisms, such as the activation of voltagedependent $\mathrm{Ca}^{2+}$ channels or the release of compounds into the extracellular space, also have been reported to participate in intercellular calcium signaling propagation in several systems (Enomoto et al., 1992; Boitano et al., 1995). Glutamate and ATP are known to be released by astrocytes (Bruner et al., 1993; Parpura et al., 1994) and to act as agonists on astrocytic membrane metabotropic receptors coupled to PLC and ionotropic receptors permeable to $\mathrm{Ca}^{2+}$ (Finkbeiner, 1995). However, neither enzymatic degradation nor the use of receptor antagonists or channel blockers has affected the speed and the extent of intercellular calcium signaling in the present study. Thus, these alter- 
nate mechanisms do not participate in the propagation of intercellular calcium waves in rat cultured astrocytes.

When the ability of various receptor agonists to evoke regenerative intercellular calcium waves was tested in astrocytes, a threshold in $\left[\mathrm{Ca}^{2+}\right]_{\mathrm{i}}$ elevation in the stimulated cell was found. Interestingly, the relative ratio of Indo1 emissions for this threshold was estimated at 0.3 , a value similar to that monitored in cells located at the limit of calcium waves (see above). When measurements of IPs formation and the amplitude of agonist-induced $\mathrm{Ca}^{2+}$ responses are taken as indices of PLC activity, they suggest that the triggering and the extent of intercellular calcium signaling depend on the level of PLC activation. Consequently, the potency of an agonist to stimulate PLC activity and to produce $\mathrm{IP}_{3}$ determines its ability to trigger a regenerative intercellular calcium wave. This indicates that, in addition to its participation in propagation, PLC activation plays a critical role in the initiation of intercellular calcium signaling induced by pharmacological stimulation of membrane receptors.

The identification of multiple steps involved in astrocytic intercellular calcium signaling suggests that their initiation and propagation can be regulated at different levels. These include receptor coupling to PLC, cross-talk between signal transduction pathways interfering with PLC activation, filling or depletion of $\mathrm{IP}_{3}$-sensitive internal $\mathrm{Ca}^{2+}$ stores, regulation of $\mathrm{IP}_{3}$ receptors, and permeability of gap junctions. Such a diversity in regulation sites suggests that a certain degree of selectivity and plasticity may occur in the triggering and the patterning of pathways taken by intercellular calcium signals. Indeed, circuitous paths already had been described for calcium waves induced by glutamate applications (Finkbeiner, 1992; Venance et al., 1995) and also were observed in the present study after focal application of Et-1. This indicates that preferential routes are selected when intercellular calcium signaling is generated by the activation of membrane receptors. Increases in $\left[\mathrm{Ca}^{2+}\right]_{i}$ within astrocytes have been shown to activate some, but not all, contacting neurons (Charles, 1994; Nedergaard, 1994; Parpura et al., 1994). Therefore, these selective astrocyto-neuronal interactions may depend on the pattern of astrocytic pathways taken by intercellular calcium signals. The drawing of such preferential astrocytic networks could be determined by regulatory processes acting on the multiple steps contributing to the initiation and propagation of intercellular calcium signaling.

Finally, differences in kinetics of the various effects induced by receptor stimulation should be taken into account when interactions among astrocytes are considered. For instance, both endothelins and glutamate have been reported to control gap junctional communication among astrocytes (Giaume et al., 1992; Enkvist and McCarthy, 1994; Müller et al., 1996). However, this regulation occurs with a different time scale, as compared with the propagation of intercellular calcium waves (minutes vs seconds). Thus, receptor stimulation may have several time-dependent effects on intercellular glial signaling: first the triggering of intercellular calcium signaling and then the inhibition or facilitation of the permeability of gap junction channels, which could exert a delayed control on the propagation of further intercellular calcium signals.

\section{REFERENCES}

Allbritton NL, Meyer T, Stryer L (1992) Range of messenger action of calcium ion and inositol 1,4,5-trisphosphate. Science 258:1812-1815. Attwell D (1994) Glia and neurons in dialogue. Nature 369:707-708.

Bender AS, Neary JT, Norenberg MD (1993) Role of phosphoinositide hydrolysis in astrocyte volume regulation. J Neurochem 61:1506-1514.
Bennett MVL, Barrio LC, Bargiello TA, Spray DC, Hertzberg EL, Saez JC (1991) Gap junctions: new tools, new answers, new questions. Neuron 6:305-320.

Boitano S, Dirksen ER, Sanderson MJ (1992) Intercellular propagation of calcium waves mediated by inositol trisphosphate. Science 258:292-295.

Boitano S, Woodruff ML, Dirksen ER (1995) Evidence for voltagesensitive, calcium-conducting channels in airway epithelial cells. Am J Physiol 269:C1547-C1556.

Bruner G, Simmons ML, Murphy S (1993) Astrocytes: targets and sources for purines, eicosanoids, and nitrosyl compounds. In: Astrocytes: pharmacology and functions (Murphy S, ed), pp 89-108. San Diego: Academic.

Carter TD, Chen XY, Carlile G, Kalapothakis E, Ogden DC, Evans WH (1994) Cultured porcine aortic endothelial gap junctions: characterization and permeation by second messenger molecules. J Physiol (Lond) 475:74P.

Charles AC (1994) Glia-neuron intercellular calcium signalling. Dev Neurosci 16:196-206.

Charles AC, Merrill JE, Dirksen ER, Sanderson MJ (1991) Intercellular signaling in glial cells: calcium waves and oscillations in response to mechanical stimulation and glutamate. Neuron 6:983-992.

Charles AC, Naus CCG, Zhu D, Kidder GM, Dirksen H, Sanderson MJ (1992) Intercellular calcium signaling via gap junctions in glioma cells. J Cell Biol 118:195-201.

Charles AC, Dirksen ER, Merrill JE, Sanderson MJ (1993) Mechanisms of intercellular calcium signaling in glial cells studied with dantrolene and thapsigargin. Glia 7:134-145.

Christ GJ, Moreno A, Melman A, Spray DC (1992) Gap junctionmediated intercellular diffusion of $\mathrm{Ca}^{2+}$ in cultured human corporal smooth muscle cells. Am J Physiol 263:C373-C383.

Clapham DE (1995) Calcium signaling. Cell 80:259-268.

Cornell-Bell AH, Williamson A (1993) Glutamate-induced hyperexcitability of astrocytes and neurons in epileptic human cortex associated with tumors. In: Biology and pathology of astrocytes-neurons interactions (Fedoroff, S. Burkholder G, eds), pp 51-65. New York: Plenum.

Cornell-Bell AH, Finkbeiner SM, Cooper MS, Smith SJ (1990) Glutamate induces calcium waves in cultured astrocytes: long-range glial signaling. Science 247:470-473.

Dani JW, Chernjavsky A, Smith SJ (1992) Neuronal activity triggers calcium waves in hippocampal astrocytes networks. Neuron 8:429-440.

Dermietzel R, Hertzberg H, Kessler JA, Spray DC (1991) Gap junction between cultured astrocytes: immunocytochemical, molecular, and electrophysiological analysis. J Neurosci 11:1421-1432.

El Etr M, Cordier J, Glowinski J, Prémont J (1989) A neuro-glial cooperativity is required for the potentiation by 2-chloroadenosine of the muscarinic sensitive phospholipase C. J Neurosci 9:1473-1480.

El Fouly MH, Trosko JE, Chang CC (1987) Scrape-loading and dye transfer: a rapid and simple technique to study gap junctional intercellular communication. Exp Cell Res 168:422-430.

Enkvist MOK, McCarthy KD (1992) Activation of protein kinase C blocks astroglial gap junction communication and inhibits the spread of calcium waves. J Neurochem 59:519-526.

Enkvist MOK, McCarthy KD (1994) Astroglial gap junction communication is increased by treatment with either glutamate or high $\mathrm{K}^{+}$ concentration. J Neurochem 62:489-495.

Enomoto K, Furaya K, Yamagishi S, Maeno T (1992) Mechanically induced electrical and intracellular calcium responses in normal and cancerous mammary cells. Cell Calcium 13:501-511.

Finkbeiner SM (1992) Calcium waves in astrocytes-filling the gaps. Neuron 8:1101-1108.

Finkbeiner SM (1993) Glial calcium. Glia 9:83-104.

Finkbeiner SM (1995) Modulation and control of intracellular calcium. In: Neuroglia (Kettenmann H, Ransom BR, eds), pp 273-288. New York: Oxford UP.

Giaume C, Fromaget C, El Aoumari A, Cordier J, Glowinski J, Gros D (1991a) Gap junctions in cultured astrocytes: single-channel currents and characterization of channel-forming protein. Neuron 6:133-143.

Giaume C, Marin P, Cordier J, Glowinski J, Prémont J (1991b) Adrenergic regulation of intercellular communication between cultured astrocytes from the mouse. Proc Natl Acad Sci USA 88:5577-5581.

Giaume C, Cordier J, Glowinski J (1992) Endothelins inhibit junctional permeability in cultured mouse astrocytes. Eur J Neurosci 4:877-881.

Grynkiewicz G, Poenie M, Tsien RY (1985) A new generation of $\mathrm{Ca}^{2+}$ 
indicators with greatly improved fluorescence properties. J Biol Chem 260:3440-3450.

Hansen M, Boitano S, Dirksen ER, Sanderson MJ (1995) A role for phospholipase $\mathrm{C}$ activity but not ryanodine receptors in the initiation and propagation of intercellular calcium waves. $\mathrm{J}$ Cell Sci 108:2583-2590.

Jin W, Lo TM, Loh HH, Thayer SA (1994) U73122 inhibits phospholipase C-dependent calcium mobilization in neuronal cells. Brain Res 642:237-243.

Kandler K, Katz LC (1995) Neuronal coupling and uncoupling in the developing nervous system. Curr Opin Neurobiol 5:98-105.

Khodakhah K, Ogden D (1993) Functional heterogeneity of calcium release by inositol trisphosphate in single Purkinje neurons, cultured cerebellar astrocytes, and peripheral tissues. Proc Natl Acad Sci USA 90:4976-4980.

Marin P, Delumeau J-C, Durieu-Trautmann O, LeNguyen D, Prémont J, Strosberg AD, Couraud PO (1991) Are several G-proteins involved in the different effects of endothelin-1 in mouse striatal astrocytes? J Neurochem 56:1270-1275.

Müller T, Möller T, Neuhaus J, Kettenmann H (1996) Electrical coupling among Bergmann glial cells and its modulation by glutamate receptor activation. Glia 17:274-284.

Murphy N, Cordier J, Glowinski J, Prémont J (1994) Is protein kinase C activity required for the $N$-methyl-D-aspartate-evoked rise in cytosolic $\mathrm{Ca}^{2+}$ in mouse striatal neurons? Eur J Neurosci 6:854-860.

Nathanson MH, Burgstahler AD, Mennone A, Fallon MB, Gonzalez CB, Saez JC (1995) $\mathrm{Ca}^{2+}$ waves are organized among hepatocytes in the intact organ. Am J Physiol 269:G167-G171.

Nedergaard M (1994) Direct signaling from astrocytes to neurons in cultures of mammalian brain cells. Science 263:1768-1771.

Nedergaard M, Cooper AJL, Goldman SA (1995) Gap junctions are required for the propagation of spreading depression. J Neurobiol 28:433-444

Osipchuk Y, Cahalan M (1992) Cell-to-cell spread of calcium signals mediated by ATP receptors in mast cells. Nature 359:241-244.
Parpura V, Basarsky TA, Liu F, Jeftinija K, Jeftinija S, Haydon PG (1994) Glutamate-mediated astrocyte-neuron signalling. Nature 369:744-747.

Robb-Gaspers LD, Thomas AP (1995) Coordination of $\mathrm{Ca}^{2+}$ signaling by intercellular propagation of $\mathrm{Ca}^{2+}$ waves in the intact liver. $\mathrm{J}$ Biol Chem 270:8102-8107.

Saez JC, Connor JA, Spray DC, Bennett MVL (1989) Hepatocyte gap junctions are permeable to the second messenger, inositol 1,4,5trisphosphate, and to calcium ions. Proc Natl Acad Sci USA 86:2708-2712.

Sanderson MJ, Charles AC, Boitano S, Dirksen ER (1994) Mechanisms and function of intercellular calcium signalling. Mol Cell Endocrinol 98:173-187.

Smith SJ (1994) Neuromodulatory astrocytes. Curr Biol 4:807-810.

Smith RJ, Sam LM, Justen JM, Bundy GL, Bala GA, Bleasdale JE (1990) Receptor-coupled signal transduction in human polymorphonuclear neutrophils: effects of a novel inhibitor of phospholipase C-dependent processes on cell responsiveness. J Pharmacol Exp Ther 253:688-697.

Stella N, Tencé M, Glowinski J, Prémont J (1994) Glutamate-evoked release of arachidonic acid from mouse brain astrocytes. J Neurosci 14:568-575.

Takeda M, Nelson DJ, Soliven B (1995) Calcium signaling in cultured rat oligodendrocytes. Glia 14:225-236.

Venance L, Piomelli D, Glowinski J, Giaume C (1995) Inhibition by anandamide of gap junctions and intercellular calcium signalling in striatal astrocytes. Nature 376:590-595.

Willems PH, Van-de-Put FH, Engbersen R, Bosch RR, Van-hoof HJ, de-Pont JJ (1994) Induction of $\mathrm{Ca}^{2+}$ oscillations by selective, U73122mediated depletion of inositol-trisphosphate-sensitive $\mathrm{Ca}^{2+}$ stores in rabbit pancreatic acinar cells. Pflügers Arch 427:233-243.

Xia S-L, Ferrier J (1992) Propagation of a calcium pulse between osteoblastic cells. Biochem Biophys Res Commun 186:1212-1219.

Yuste R, Nelson D, Rubin W, Katz LC (1995) Neuronal domains in developing neocortex: mechanisms of coactivation. Neuron 14:7-17. 